\title{
POWER OF MEDIA, PUBLIC DIPLOMACY AND FOREIGN POLICY IN THE $21^{\text {st }}$ CENTURY
}

\author{
Huyen Trang Do \\ Diplomatic Academy of Vietnam- Vietnam Ministry of Foreign Affairs
}

\begin{abstract}
Public diplomacy is used as an effort to engage and persuade foreign publics, an important factor in a foreign policy to improve the image and position of one country. The objectives of one country's foreign policy can be obtained by dealing directly with the people of foreign countries. Today, in the information age, under the power of the media of causing an effect in indirect or intangible ways, new public diplomacy is implemented as an modern instrument and techniques of communication, a shift in diplomatic practices to engage with foreign publics and move away form one-way information flows toward dialogue and engagement. Therefore, a new media landscape challenge traditional foreign ministry "gatekeeper" structures, foreign ministry of foreign affairs can no longer being a dominant factor in communicating foreign policy. It requires a new away practice to being carried out with new media, new technologies to elucidate foreign policy to a range of nongovernmental international actors, evaluate the influence of these communicative efforts. The paper will clarify the old and new theoretical framework of public diplomacy, the role and power of public diplomacy in foreign policy, the power of the media in the $21^{\text {st }}$ century which influence the new public diplomacy practices of one country in general and the United States government in specific, covering national policy, current affairs, current activities. From these analyses, the paper will be concluded the new way for Vietnam Ministry of Foreign Affairs to implement its public diplomacy in the new era of media age.
\end{abstract}

\section{Old and New Public Diplomacy}

Definition of public diplomacy has appeared in 1960s, which is a new definition of the modern international relations; however, its activities have been implemented for a long time. When the Ancient Rome invited sons of its neighbor kings to study at Rome, this was considered as primitive activity of public diplomacy, culture exchange in modern age. The other example is the building of the Royal Library of Alexandria or Ancient Library of Alexandria in Egypt, one of the largest and the most significant libraries of the ancient world, part of a larger research institution called Museum of Alexandria where many of the most famous thinkers of the ancient world studied, which could be seen as the model for British Council or Confucius Institute at present. The term "public diplomacy" has varied over the years, having been around the mid- nineteenth century and its usage initially peaked after the World War I as a liberal criticism of secretive diplomacy. It re-emerged in the 1960s as a means of interpreting Cold War propaganda and was associated during the 1980s with Reagan propaganda's activities in Latin America. The old public diplomacy in the twentieth century was considered as "a state- based instrument used by foreign ministries and other government agencies to engage and persuade foreign publics for the purpose of influencing their governments" 1 . This referred to propaganda or a kind of diplomatic advertising, which described as a one- way flow of information in which PD actors control the message by making instrumentalist use of media channels and ensuring limited interaction between communicators and "recipient", focusing on specific short-term objectives.

\footnotetext{
${ }^{1}$ Gregory, Bruce (2011), “American Public Diplomacy: Enduring Characteristics, Elusive Transformation”, The Hague Journal of Diplomacy, vol.6 (2011), pp. 351-372, (page 353).
} 
Edmund Gullion, former US Ambassador and Dean of the Edward R. Murrow Center of Public Diplomacy at the Fletcher School of Law and Diplomacy, Tuffs University first established the modern usage of this term in 1964. Based on his definition, Public Diplomacy is a form of influencing over public opinion that would in turn have an effect on the conduct of diplomacy, and "deals with the influence of public attitudes on the formation and execution of foreign policies" ${ }^{2}$. In his explanation for the communicative aspects of the public diplomacy influencing method, public diplomacy relates to the role of the press and other media in international affairs, cultivation by governments of public opinion, the non-governmental interaction of private group and interests in one country with those of another, and the impact of these transnational processes on the formulation of policy and the conduct of foreign affairs" ${ }^{, 3}$. Therefore, it can be seen the role of communication technology in carrying information of the new public diplomacy. The information age has been democratizing communication by providing freedom of access to information, the ability to voice opinions and the opportunity to enter debate. No foreign policy could be successful without a sustained, coordinated capability to understand, inform and influence people and private organizations, as well as governments ${ }^{4}$. The goals of Public Diplomacy are to understand, inform and influence and the changes in communication technology had affected how PD actors can reach target publics, the number of actors with an active stake in foreign affairs, and public expectations of how governments should related to them. Comparisons between old and new PD are paralleled with differences between old and new media. The new technologies challenges the process of understanding, informing and influencing, which is the way PD actors engaged with their publics. International researchers stated that public diplomacy would include activities in the fields of information, education, culture to influence the other foreign governments through their citizens. In his book "The New Public Diplomacy: Soft-power in International Relations", Jan Melissen defined a new public diplomacy as "a shift in diplomatic practices motivated by new actors; engagement with increasingly "interconnected foreign publics"; moving away from one-way information

flow towards dialogue and engagement". ${ }^{5} \mathrm{He}$ also mentioned that US post- 9/11 public diplomacy has been considered as the solution for global challenges such as terrorists, Iraq war... while the other traditional diplomatic methods could not deal with conflicts in international relations.

\section{Public Diplomacy in the Information Age}

\section{In terms of Strategic Overview:}

New information technologies have accelerated and expanded the global inter- relations among countries, corporations, organizations, people and individual citizens.

In such an interdependent world, national governments have realized the importance of the Internet and other new media tools in promoting their public diplomacy efforts. Connectivity and interactivity have become the defining characteristics of the new media, as well as the defining communication activity of their users.

${ }^{2}$ Waller, J. Michael (ed.) (2007), The Public Diplomacy Reader. Washington, DC: The Institute of World Politics Press. (page 23).

${ }^{3}$ Waller, J. Michael (ed.) (2007), The Public Diplomacy Reader. Washington, DC: The Institute of World Politics Press. (page 24).

${ }^{4}$ Peterson, Peter G., Sied. Jenifer, Bloomgarden, Kathy (2002), Public Diplomacy: A Strategy for Reform: Report of an Independent Task Force on Public Diplomacy Sponsored by the Council on Foreign Relations. Washington DC. Council on Foreign Relations (page 5).

${ }^{5}$ Mellisen, Jan (ed.) (2005), The New Public Diplomacy: Soft Power in International Relations, Basingstoke, UK: Palgrave Macmillan. 
Social media has transformed from the Web as passive information communication to a dynamic platform for the exchange of real experience, since self- expression, participation, dialogue as well as creation and maintenance of relationships within virtual communities becomes possible.

\begin{tabular}{|c|c|c|}
\hline Main characteristics & Old Public Diplomacy & New Public Diplomacy \\
\hline 1. Identity of Key Actor & State & State \& non- state \\
\hline $\begin{array}{l}\text { 2. Key Objective, Background \& } \\
\text { Context }\end{array}$ & $\begin{array}{l}\text { Linked to foreign policy \& } \\
\text { national security } \\
\text { Outgrowth of political advocacy \& } \\
\text { propaganda theory } \\
\text { Crisis- driven and reactive }\end{array}$ & $\begin{array}{l}\text { Longer- term in reference to } \\
\text { behavioral change } \\
\text { Based on relationship, systems \& } \\
\text { network consideration } \\
\text { Outgrowth of corporate branding } \\
\text { \& network theory } \\
\text { Linking Branding with Social } \\
\text { Media }\end{array}$ \\
\hline 3. Nature of Transaction & $\begin{array}{c}\text { Official, Quasi- Official and } \\
\text { Unofficial } \\
\text { Top down: actor to foreign peoples } \\
\text { Targeted messaging }\end{array}$ & $\begin{array}{l}\text { Mainly Unofficial/ Non- } \\
\text { governmental (NGOs, private } \\
\text { citizens, practitioners) } \\
\text { Horizontal, facilitated by actor: } \\
\text { Relationship-branding }\end{array}$ \\
\hline $\begin{array}{l}\text { 4. Government \& Public } \\
\text { Involvement }\end{array}$ & $\begin{array}{l}\text { Government to publics }(\mathrm{G} 2 \mathrm{P}) \\
\text { Passive public role }\end{array}$ & $\begin{array}{c}\text { Publics to Publics (P2P) } \\
\text { transmission } \\
\text { Active \& participatory public }\end{array}$ \\
\hline 5. Communication Flow & $\begin{array}{l}\text { One- way informational; two-way } \\
\text { asymmetric } \\
\text { Unequal partners in information } \\
\text { and/or communication }\end{array}$ & $\begin{array}{c}\text { Dialogue- based } \\
\text { Exchange orientation- --two-way } \\
\text { symmetric communication }\end{array}$ \\
\hline 6.Technological Environment & $\begin{array}{l}\text { Short-wave radio, print } \\
\text { newspapers, land-line telephones } \\
\text { Necessary evil as technology and } \\
\text { new media democratized } \\
\text { international relations }\end{array}$ & $\begin{array}{l}\text { Satellite, Internet, real-time news } \\
\text { Mobile telephones }\end{array}$ \\
\hline 7. Media Environment & $\begin{array}{l}\text { Clear line between domestic \& } \\
\text { international news sphere }\end{array}$ & $\begin{array}{l}\text { Blurring of domestic \& } \\
\text { international news sphere }\end{array}$ \\
\hline 8. Terminology & "International image" "Prestige" & "Soft power", "National brand" \\
\hline
\end{tabular}

In this new environment, public diplomacy activities become more personalized. Social networking, blogging, micro-blogging and other new media tools have given individual citizens the opportunity to communicate with agents of public diplomacy, who are perceived as being "some-one like me" rather than impersonal nationstate. Furthermore, old public diplomacy described as one-way communication has been replaced by sharing information, experience and interaction.

\section{Less relevance to the Competitive Cold War Model}

Promoting positive images of one's country is not new, but the conditions for implementing soft power have transformed dramatically in recent years. Nearly half the countries in the world are now democracies. The competitive cold war model becomes less relevant as a guide for public diplomacy. 
While it is necessary to provide accurate information to people in countries where the government controls information, there is a new demand to garner favorable public opinion in countries where parliaments can influence decision-making.

Moreover, shaping public opinion will become more important where authoritarian governments have been replaced. Public support would not so important when the United States successfully sought the use of bases in authoritarian countries, but it became crucial under the new democratic conditions in Mexico and Turkey. Even when foreign leaders are friendly, their freedom to act may be limited if their publics have a negative image of the United States. Then Diplomacy aimed at public opinion would become important outcomes as the traditional classified diplomatic communications among leaders.

\section{The Paradox of Plenty (of Information)}

Nowadays, information is power, and most of the world's population has access to that power. It has been ages when "small teams of foreign service officers drove Jeeps to the hinterlands of remote regions of the worlds to show reel - to- reel movies to isolated and passive audiences. Technological advances leads to a considerable reduction in the cost of processing and transmitting information. The result is that an explosion of information and produced a "paradox of plenty". Plenty of information would lead to scarcity of attention. When people are overwhelmed with the volume of information, they find it difficult to know what has to be focused on. Therefore, attention rather than information has become the scarce resource, and those who can differentiate valuable information from background clutter gain power. Editors, specialists and cue- givers become more in demand, and this is a source of power for those who can tell people where to focus our attention.

\section{Credibility}

Among editors and cue-givers, credibility is the important resource and more crucial than in the past, the political struggles would occur over the creation and destruction of credibility. Governments will compete for credibility not only with other governments but also with a broad range of actors including news media, corporations, NGOs, intergovernmental organizations, and networks of scientific communities. Politics has become a competition of competitive credibility.

Under the new conditions of the information age, the soft power may prove more effective. A weak credibility and the public diplomacy will not translate culture resources into the soft power of attraction. The effectiveness of public diplomacy is measured by minds changed (as shown public polls), not dollars spent or slick production packages.

The professional production values of the new American satellite television station Alhurra did not make it competitive in the Middle East, where it was widely regarded as an instrument of government propaganda. The effectiveness of public diplomacy is measured by minds changed (as shown in interviews or polls), not dollars spend. For example, the professional production values of the new American satellite television station Alhurra could not make it competitive in the Middle East, where it was widely considered as an instrument of government propaganda. The effectiveness of public diplomacy is measured by minds changed (as shown in interviews or polls), not dollar spent.

\section{The rise of soft power in international relations}

The Word War I saw the appearance of professional image cultivation across national borders, and it was inevitable after the war that the emerging academic study of international politics would wake up to the importance of "soft power, which introduced by Joseph S. Nye, "hard power" and "soft power" are inextricably linked. Today, soft- power, which is the postmodern variant of power over opinion, becomes increasingly important in the global information age. Political specialists in many countries have been become gripped by the notion of soft power and the Ministries of foreign affairs wonder how to implement it most effectively. As Nye mentioned, countries that are likely to be more attractive in post modern international relations are those that could frame issues, whose culture and ideas are closer to prevailing international norms, and whose credibility abroad is reinforced by their values and policies (Nye, 2004). And public diplomacy is one of the factors of soft 
power, which is "based on intangible or indirect influences such as culture, values and ideology" (Nye, 1990). Joseph Nye defines power, as "the ability to influence the behavior of others to get the outcomes one wants" and mentioned three ways to do that: 1) coerce with threats; 2) induce behavioral change with payments; or 3) attract and co-opt. Soft power is getting others to appreciate you to the extent that they change their behavior to your liking. Sources of soft power would be based on culture, political values and foreign policy. What gives any country a soft power advantage is measure by three dimensions:

- When culture ad ideas match prevailing global norms

- When a nation has greater access to multiple communication channels that can influence how issues are framed in global news media.

- When a country's credibility is enhanced by domestic and international behavior.

Nye emphasized public diplomacy being a tool to convey the message and mobilize sources to create soft power. Therefore, public diplomacy plays an important role to implement foreign policy to realize the soft power of country. It could be understand that "public diplomacy is the country's attempts to implement foreign policy and pursued the national interests through directly dealing and engaging with the people of foreign countries and non-state actors".

Public diplomacy is one of soft power's key instruments, and this was recognized in diplomatic practice long before the contemporary debate on public diplomacy. The United States, the former Soviet Union and Europe's three major powers invested particularly heavily in their "communications with the world' during the Cold War. Although conventional diplomatic activity and public diplomacy were mostly pursued on parallel tracks, it became increasingly hard to see how the former could be effective without giving sufficient attention to the latter. It fact, as early as 1917-18, Wilson and Lenin had already challenged one another at the soft power level, long before their countries turned into global superpowers and started colliding in the military and economic fields. The batter of values and ideas that dominated international relations in the second half of the twentieth century evolved into competition in the sphere of hard power, and not vice versa. The world diplomatic community woke up late to the fundamental challenges of communication with foreign publics rather than habitual international dialogue with foreign officials. Diplomatic culture is after all fundamental peer- oriented, and the dominant realist paradigm in diplomatic circles was by- product of a long history of viewing international relations in terms of economic and military power. The question today of how foreign ministries can instrumentalize soft power is testing their diplomats' flexibility to the full. As Robert Cooper said that success in diplomacy "means openness and transnational cooperation"6, such openness and multi- level cooperation call for the active pursuit of more collaborative diplomatic relations with various types of actors. Public diplomacy is an dispensable ingredient for such a collaborative model of diplomacy". 7

"If you look at expenditures in the American budget, we spent about 17 times as much on military hard power as we do on all our foreign representation, the State Department budget, foreign aid as well as the Voice of America and all the exchange programs lumped together. There is something wrong with that picture" (Nye, 2004).

Similar Experience in UK: With the Ministry of Defence receiving 18 times the amount of the Foreign Common Wealth Office (FCO) (24.2 billion pounds compared to 1.3 billion pounds), the investment in public diplomacy is dwarfed by the returns that come from successful work- and the cost of failure. For example, the

\footnotetext{
${ }^{6}$ Robert Cooper, the Breaking Nations: Order and Chaos in the Twenty- first century (London: Atlantic Books, 2003), p.76.

${ }^{7}$ Shaun Riordan, The New Diplomacy (London: Polity, 2003), chapter 9.
} 
200,000 foreign students that the British Council works to attract every year earn 5 billion pounds for British higher education. Equally, the disastrous images that came out of Foot and Mouth have already cost an estimated 2 billion pounds in lost tourist revenue.

Diplomatic institutions need to move beyond cosmetics of locking on a few units and recruiting some extra staff from NGOs. Instead, what is needed is a fundamental re-balancing of the diplomatic offer and a larger investment in it. Foreign services must transform themselves from being reporters and lobbyists on reactive issues to shapers of public debates around the world.

\section{Media Power to Foreign Policy}

The classic four functions of the media are: first, surveillance of the environment, which concerns the media collecting and distributing information; second, correlation of the parts of society to respond the environment; third, the transmission of the social heritage from one generation to the next, referring to the mass media being able to communicate different values, social norms across different groups and throughout long periods of time (Lasswell, 197: 85); entertainment and mobilization (Mc Quail, 1994).

In providing the foreign- policy environment, there of these roles are relevant: the informative, the correlative, mobilizing functions. In performing these functions, the mass media incorporate and integrate the national society as part of the internal environment.

Reporters would inform the public of international, foreign and security events; journalists provide background, interpretation and commentary on the information. In its third role, the media provide support to the established authority and its norms, especially during crisis or a peace process. Then the press performs its mobilizing role, which creates a joint media- government environmental component.

There are three main modes of influence, which the media have on foreign policy. First, agenda setting means "the mass media may not be successful in telling people what to think", however "the media are successful in telling their audience what to think about" $" 8$. Television plays a major agenda setting impact. Second, the main impact of the media is "framing" and "priming" which lead to shape public opinion. The stakes related to a particular foreign policy issue, which are not necessary to be self-evident or part of an objective reality. How issue is cast (Framed) influenced the substantive judgments of people and then the media plays an important role in the framing. The media also affects (prime) the relative priority that the publics give to an issue over another and the criteria by which the public makes their judgments about success or failure. These effects occur both directly through the public's own exposure to the media and indirectly through opinion leaders, cue-givers. Third, the media influence directly on policy- makers, which their concerns wonder how a policy could be perceived comes into a play part of the plans for pursuing a foreign policy, with strategies for press conferences, special briefings and political spins almost as detailed as military plans. Moreover, smart policy- makers focus on dispatches and analyses by the more famous foreign affairs journalists as independent sources of information to supplement their own intelligence sources.

\section{Public Diplomacy Communication Process in the Information Age}

Based on Cull's recent work in which he identified five core components of public diplomacy, these are: listening, advocacy, cultural diplomacy, exchange diplomacy, international broadcasting (Cull, 2009).

Listening is the first which precedes the success of PD, identified by Cull as the element which "preceds all successful public diplomacy", listening encompasses information gathering on the context in whih

${ }^{8}$ Arthur M. Schalesinger, Jr., The Imperial Presidency (New York: Atlantic Monthly Press, 1974), 51-51. 
communication takes place. Theold public diplomacy actor would use many methods to collect information on foreign environment to better affect it. First, Media monitoring is the practice of collecting data from foreign television, radio and news paper sources and making assessments on how a nation is being represented abroad for the purpose of engaging with those representations. Second, Public opinion polling which is a means of assessing how members of the public respond to the representation of a country and set of policies. The point of collecting data through listening is that it should then be used as a basic for decision-making- a process that has not been given attention it deserves and has become a fundamental point of contention for the new PD (Kelley, 2009).

Listening is considered as an attempt to manage the international environment by collecting and collating data about publics and their opinions overseas and using that data to redirect its policy or its wider public diplomacy approach accordingly (Cull, 2009).

Traditionally undervalued, listening has increasingly been assimilated into the dialogical and advisory communication models proposed by advocates of the new public diplomacy. One of the ideals of the new PD is that communication (and even policy) decisions should be taken on the basic of up- to- date data for the purposes of engagement, rather than on the basic of static preconceptions for unindirectional broadcasting. Listening therefore offers a pretext for influencing foreign media environments- often reactively, through potentially proactively if research informs policy- through information gathering and analysis.

Advocacy is the promotion of policies, ideas or interests to foreign public in an attempt to affect their opinions. This includes most prominently Foreign Ministry or Embassy press relations, lobbying and information work, and tends to have short-term uses and goals (Cull, 2008). Since public diplomacy targets are in foreign publics, advocacy work plays out in the media and political environments of other nations and is designed to influence the political climate. "Advocacy is a uni- directional transmission of information, often geared to meet shortterm needs, and sometimes moved to communicate in an influence- driven, propagandistic communication style" (Kelley, 2009) ${ }^{9}$.

New PD theories considered advocacy work as dialogue based, building on like- minded networks of government and non-governmental actors, with research informing the strategy and engagme nt as well as collaboration providing the basis for persuasion. ${ }^{10}$

Cultural and exchange diplomacy is a nation's effort to manage the international environment through promotion of cultual resources and achievements overseas. It including tours, promotions and institutes for culture, art and language, being a means of promoting a nation's values through dialogue and exchange with other culture, art and language,also a means of promoting a nation's values through dialogue and exchange with other cultures in the long term, and promotes relationship- building, trust and mutuality. Moreover, cultural diplomacy relates to the negotiation of formal bilateral agreements over cultural promotions or exchanges. For instance: the international tour of a national state theatre or ballet, emphasizing the "execution of these agreements and the implementation of cultural relations flowing from them. Traditionally, the goal is to promote

9 Kelley, John Robert (2009) Between "Take- offs" and "Crash Landings": situational aspects of Public Diplomacy, pp. 72-85 of Snow, Nancy \& Taylor, Philip M. (eds) Routledge Handbook of Public Diplomacy. London \& New York: Routledge.

${ }^{10}$ Evan, Alex and Steven, David (2008) Towards a Theory of Influence for Twenty First Century Foreign Policy: Public Diplomacy in a Globalized World, pp. 44-61 of Welsh, Joylon and Fearn Daniel (eds) Engagement: Public Diplomacy in a Globalized World. London: Foreign \& Commonwealth Office. 
issues which have mutual benefits to the citizens of both countries, and which may improve the climate for the diplomatic negotiations when relations are under pressure.

Today, cultural diplomacy has been reversed for creating experiences rather than simply transmitting information; therefore, positioning it (along with exchange diplomacy) as one of the new public diplomacy components. In a long term, the new public diplomacy could be considered a expansion and generalisation of well- established cultural relations communication models into other public diplomacy components.

Exchange diplomacy relates to visits between citizens of different nations and the positive role this performs in generating international understanding. Exchange participants are sometimes considered "citizen diplomats" as unofficial ambassadors sharing the responsibility to help shape foreign relations. One country sends its citizen overseas and reciprocally accepts citizens from the overseas, often, these are targeted to have leadership, educational, military or culural importance. A typical strategy is a for the Ministry of Foreign Affairs to host journalists, such as educational scholarships are well- establised models of exchange.

Exchange diplomacy depends on the "opinion leader" or "multiplier" model of communication, which regards respectable community members relaing their personal experiences of foreign cultures to larger publics in a manner that is more convincing than mass communication. Business and special interest actors have become prominent citizen diplomacy actors, however historically religious and missionary groups are perhaps the most significant motivators of citizen diplomacy. New public diplomacyemphasizes the role of actors from business, enterntainment, education and diasporas in promoting international understanding.

International broadcasting (News) through radio, TV and Internet- Governmental \& Commercialmakes use of media techonologies and media power to provide information for foreign publics. The broadcasting channels could be wholly- owned and controlled by a government agency, or come under the independent editorial control of private or non goverment institution with partial government support or guidance. Broadcasting can play direct or indirect roles in government public diplomacy objectives, such as monitoring functions, advocacy work, cultural and artistic promotion and exchanges of programming and personne or in a broader sense, include interviews with official on private sector networks (Cull, 2008).

Recent techonological advances have present major challenges to successful Cold War broadcasting business models such the Voice of America and Radio Free Europe. In the The Gulf War, the birth of the "The CNN effect", in which transnational satellite media pushed policy decision makers to take action according to news agenda deadlines, thereby intervening in their usual decision- making cycles. Recently, Moises Nain called the term "YouTube effect" to describe how community websites such as YouTube challenged military attemps to control the image of warfare during the 2003 Iraq war. This trend is contributed by the collaborative, interative nature of new media such as "wikis", blogs and social network, which can be characterised as representing a paradigm transform from "I" to "We" media. Diplomats are facing to engage more in online communication about their policies to influence, since online techonolies are considered "essential tools" for public communication.

This overview demonstrates that each of the traditional components of old public diplomacy is challenged by the new public diplomacy. Listening is regarded as prerequisite for understanding and influencing foreign publics, amid increasing expectations that policy shoud be more directly informed by the analysis of foreign opinion, and more flexible to the demands of dialogue. This means that organisation, planning and evaluation take a more central role. Both advocacy and broadcasting are challenged to change their ways of distributing information by encouraging participation and interactivity. For advocacy work in particular, finding the right communication channel in an newer models of engagment. In culture and exchanges, there is an requirement that members of the public assume the key role in international engagement, generating transnational ties, learning about others and affecting foreign citizens through experiences.

In the information age, the new public diplomacy will have these characteristics, including credibility, unoffficial, strategic and long-term, two way engagement and multi-levels or multi-function, multi- 
collaboration. Therefore, the implementation Forms of PD includes 4 types of activities: message transmission, communication strategy, exchange and cooperation activities, trust and credibility building.

\section{The US Public Diplomacy and Lessons for Vietnam}

In the 21st century, under the government of Barack Obama, public diplomacy policy became an effective tool to realize the US national interest and its global direction. Through its available resources, the Obama government attempted to build a global community network to implements the US public diplomacy objectives.

The main components of the US public diplomacy emphasized listening; advocacy; cultural and exchange diplomacy and international broadcasting. First, in term of listening, media monitoring is carried out by the officers at overseas posts. The US main media monitoring centre is only available to the US governement employees and contractors. The Open Source Center monitors and translates news from print, radio, television, blogs, chat room sources from around the world, had the total expenditure of approximately $\$ 19$ million per year. The Office of Research which is under the State Department, implements opinion pollings and focus groups in over 50 countries with a total yearly budget of $\$ 3$ million. Think- tanks and businesses such as the Pew Research Center, Freedom House and Gallup implements main international surveys which contributes to policy making process. Second, the US advocacy to promote international understanding accounts for $3.69 \%$ of the State Department's budget, which included daily communications through explaining policies to media and responding to crises and misinformation; specific themes communication and long-term reationship building. The target public are considered as "key influencers" such as educators, journalists, labor leaders, political leaders...; vulnerable population (females, youth, minorities) and "mass audiences". In 2008, the State Department organized 160 Foreign Press Center Briefings and 55 tours with 1,700 participants from members of the foreign press which based in the US (The US State Department, 2009). Third, the US government runs 250 exchanges programs with 1.4 million foreign participants and 50,000 US citizens in 2007, with the funding of $\$ 2.2$ billion. The cultural programs includes arts, culture and literary promotional programes, being organised by the National Endowment for Arts (NEA). Last, international broadcasting is impleamented by the Broadcasting Board of Governors (BBG), being the independent federal agency and runs government- sponsored broadcasting with the annual budget of $\$ 714$ million (2009), broadcasting more than 3,000 hours of programing in 60 languages to an audience of 170 million per week. Its goal is to enhance freedom and democracy, promote understanding through multimedia communication of accurate, objective news, information and other programming about the US and the world to audiences overseas.

In brief, the US public diplomacy has these characteristics. First: the US is the superpower with its global interest. Therefore, its public diplomacy aims to the global level. Second, the public diplomacy is identified with state diplomacy to realize the US foreign policy main objectives to promote its values, prosperity and image. Third, the US public diplomacy is not only gains the support from foreign publics but also the American for its policy. Fourth, the actors of the US public diplomacy include the officials as well as the American citizens. Last, the US public diplomacy emphasizes the exchange educational programs.

In Vietnam, because of historical context, Public Diplomacy is unpopular term although in reality, many Vietnam diplomatic activities belongs to the Public diplomacy framework. The Vietnam public diplomacy will include 3 main pillars: politics diplomacy, economic diplomacy, and culture diplomacy. Those activities aim to create a peaceful environment, stability and favorable conditions for building and promoting the image and position of Vietnam in the region and in the world. With its capabilities and soft power, Vietnam could foster the efficiency of those activities that need to put into the modern Public Diplomacy framework like the US and other countries. In domestic, Vietnam should strengthen its soft power. Since the $8^{\text {th }}$ National Congress of the Communist Party of Vietnam, Vietnam confirmed the definition of "integration" officially when its relationship with other countries are enlarged. The Communist Party of Vietnam affirmed that " active international integration" was institutionalized in the $22^{\text {nd }}$ Resolution of Vietnam Political Bureau of the Party Central 
Committee on $10^{\text {th }}$ April $2013^{11}$. Therefore, with the aim to integrate actively, Vietnam should learn from other countries. In the information age, there are some lessons for Vietnam, including:

- Official definition and perspectives of Public Diplomacy's role and position in foreign policy decision making and implementation.

- Public Diplomacy policy, strategy and activities setting based on soft power of the country (culture, identity, values...), power of media.

- Public Diplomacy activities' implementation: diversified forms and coordinated among culture, political, economics diplomacy.

- Diversified main actors of Public Diplomacy.

- Identify challenges of new media and apply new media in implementing Public Diplomacy.

- Take advantages of the power of media.

Based on these lessons, the recommendations for Vietnam will include:

1. Promoting all domestic (soft power) and international conditions to implement Public Diplomacy policy.

2. Building Public Diplomacy strategic Policy.

3. Soft power and media should be key factors to implement PD policy.

4. Culture Diplomacy and Foreign Information- main components of Public Diplomacy.

5. Capacity building and cooperation among Ministries and within Ministry of Foreign Affairs.

6. Using Social Media- Apply New Media for Public Diplomacy.

7. Promoting Credibility and Trust Building Public Diplomacy Activities.

In conclusion, public diplomacy is considered as an important factor in a foreign policy to improve the image and position of one country. In the information age, Vietnam should learn how to implement its public diplomacy effectively in order to realize its national interest as well as promote its image, which has to identify its objectives, map out plans, strategy and specific public diplomacy activities based on its soft power and its economic, social conditions, along with cooperation and collaboration among state and non- state governmental actors.

\section{References}

Arthur M. Schalesinger, Jr., The Imperial Presidency (New York: Atlantic Monthly Press, 1974), p.p. 51-51.

Gregory, Bruce (2011), “American Public Diplomacy: Enduring Characteristics, Elusive Transformation”, The Hague Journal of Diplomacy, vol.6 (2011), pp. 351-372, (page 353).

Kelley, John Robert (2009) Between "Take- offs" and "Crash Landings": situational aspects of Public Diplomacy, pp. 72-85 of Snow, Nancy \& Taylor, Philip M. (eds) Routledge Handbook of Public Diplomacy. London \& New York: Routledge.

Mellisen, Jan (ed.) (2005), The New Public Diplomacy: Soft Power in International Relations, Basingstoke, UK: Palgrave Macmillan.

${ }^{11}$ http://www.mofahcm.gov.vn/vi/mofa/cs_doinoai/ns140217213857 
Proceedings of the $4^{\text {th }}$ World Conference on Media and Mass Communication, Vol. 4, 2018, pp. 35-45

Peterson, Peter G., Sied. Jenifer, Bloomgarden, Kathy (2002), Public Diplomacy: A Strategy for Reform: Report of an Independent Task Force on Public Diplomacy Sponsored by the Council on Foreign Relations. Washington DC. Council on Foreign Relations.

Waller, J. Michael (ed.) (2007), The Public Diplomacy Reader. Washington, DC: The The Institute of World Politics Press. 